The Canadian Mineralogist

Vol. 39, pp. 547-556 (2001)

\title{
WHY ARE THERE NO MAJOR Ni-Cu SULFIDE DEPOSITS IN LARGE LAYERED MAFIC-ULTRAMAFIC INTRUSIONS?
}

\author{
WOLFGANG D. MAIER ${ }^{\S}$, CHUSI LI AND SYBRAND A. DE WAAL \\ Centre for Research on Magmatic Ore Deposits, Department of Earth Sciences, University of Pretoria, Pretoria 0002, South Africa
}

\begin{abstract}
Large, layered intrusions throughout the world are characterized by a remarkable paucity in economically important magmatic Ni-Cu sulfide deposits. The Sudbury intrusion in Canada is a notable exception, but sulfide ores there were formed by a unique combination of processes involving crustal melting in response to a meteorite impact. Economically important magmatic $\mathrm{Ni}-\mathrm{Cu}$ sulfide deposits tend to occur in magma conduit systems. Such an environment has been documented at Noril'sk, Jinchuan, and the recently discovered Uitkomst deposit of South Africa and the Voisey's Bay intrusion of Labrador, Canada, which are associated with the Bushveld Complex and the Nain Plutonic Suite, respectively. The enhanced ore potential of conduit systems is attributed to their specific flow environment and to the exploitation of the conduits by multiple flows of magma. Sulfides that were entrained and transported by ascending silicate magma were concentrated in the widened parts of the conduits and, at Voisey's Bay, near the exit of the conduit into a larger chamber, owing to a decrease in the flow velocity of the magma. Further, the precipitated sulfides were upgraded by means of reaction with continued surges of undepleted magma using the same conduit. Thus, exploration for magmatic $\mathrm{Ni}-\mathrm{Cu}$ sulfide ores should be redirected from layered intrusions to their associated conduit systems.
\end{abstract}

Keywords: magmatic sulfides, Voisey's Bay, Labrador, Uitkomst, South Africa, layered intrusions, magma conduits.

\section{SOMMAIRE}

Il est remarquable que les gros massifs stratiformes au travers le monde soient si pauvres en sulfures de Ni-Cu d'origine magmatique. Le massif intrusif de Sudbury, en Ontario, est l'exception à la règle générale, mais le minerai sulfuré y est attribuable à une combinaison unique de processus impliquant fusion massive de la croûte en réponse à un impact météoritique. C'est dans les conduits magmatiques que l'on trouve les accumulations économiques importantes de sulfures massifs Ni-Cu magmatiques. Un tel milieu a été décrit à Noril'sk, à Jinchuan, à Uitkomst, gisement récemment découvert en Afrique du Sud, et à Voisey's Bay, intrusion sur la côte du Labrador, ces deux dernières associées au complexe de Bushveld et à la suite plutonique de Nain, respectivement. Nous attribuons le potential accru des systèmes de conduits aux spécificités du milieu de flux et à l'exploitation de tels conduits par plusieurs venues de magma. Les sulfures entrainés et transportés par les venues de magma silicaté sont concentrés dans les parties plus larges des conduits et, à Voisey's Bay, près de la bouche du conduit où il rejoint un réservoir plus volumineux, à cause d'une diminution de la vélocité de flux du magma. De plus, les sulfures précipités ont été enrichis par la suite par réaction continue avec des venues ultérieures de magma vierge utilisant le même conduit. Il s'avère donc nécessaire de repenser les programmes d'exploration pour les gisements de $\mathrm{Ni}-\mathrm{Cu}$ magmatiques, afin de cibler les conduits nourriciers des massifs stratiformes plutôt que les massifs eux-mêmes.

(Traduit par la Rédaction)

Mots-clés: sulfures magmatiques, Voisey's Bay, Labrador, Uitkomst, Afrique du Sud, intrusions stratiformes, conduits magmatiques.

\section{INTRODUCTION}

Since the discovery of the Sudbury Ni-Cu sulfide deposits in Canada a century ago, prospectors, geologists, and mining companies have been searching for magmatic $\mathrm{Ni}-\mathrm{Cu}$ sulfide deposits in large layered intrusions around the world. The Sudbury model suggests that magmatic sulfide orebodies occur along the base of large mafic magma chambers owing to gravitational settling of a dense sulfide liquid segregated from the parental magmas upon emplacement. Accordingly, much effort in the exploration for magmatic sulfide deposits has been devoted to the basal contacts of many large layered intrusions such as the Bushveld, Duluth,

§ E-mail address: wdmaier@nsnper1.up.ac.za 
Great Dyke, Kiglapait, Muskox, Skaergaard and Stillwater intrusions. Despite more than half a century of persistent efforts, no major $\mathrm{Ni}-\mathrm{Cu}$ sulfide deposits have been discovered. Meanwhile, economic $\mathrm{Ni}-\mathrm{Cu}$ sulfide deposits of variable sizes have been discovered in smaller conduit-type bodies such as at Jinchuan (China), Noril'sk (Russia) and, more recently, at Voisey's Bay (Labrador) and Uitkomst (South Africa). Questions arise as to how we have been misled by the Sudbury model, i.e., why other large layered intrusions do not host Sudbury-like major Ni-Cu sulfide deposits and why conduit-type bodies of much smaller size seem to be better prospects for such deposits. In this paper, we attempt to answer these questions by comparing the ore-forming processes in two conduit systems, Uitkomst, South Africa, and Voisey's Bay, Labrador and spatially associated large layered intrusions, Bushveld and Kiglapait, respectively.

\section{Sudbury: A Misleading Model}

The Sudbury intrusion consists of a fine-grained, marginal noritic "Sublayer", overlain by coarser-grained noritic, gabbroic and granophyric rocks (Naldrett 1989, and references therein). The basal contact of the body is highly irregular and characterized by embayments, a "footwall breccia", and radiating offset dykes. Sulfide ores were discovered in 1897 at the base of the intrusion, within the footwall breccia, and the country rock, particularly within and below embayments. For much of the last century, the Sudbury intrusion has been recognized to be related to an impact structure. Nevertheless, the metal budget of the ores, in particular their $\mathrm{Ni}$ and PGE contents, which are similar to those of ores formed from basaltic magmas, have led most researchers to favor a genetic model whereby the sulfides segregated from a mantle-derived magma that ascended in response to impact-induced decompression. The crust generally contains very low levels of these metals. Sulfide saturation and segregation are attributed to mixing of the mantle-derived magma with 30 to $50 \%$ of felsic melt produced by impact (Li \& Naldrett 1993). Results of recent isotopic studies (Walker et al. 1991) and thermal modeling (Grieve 1994) strongly suggest that the entire intrusion may be a sheet of impact-generated melt and that the sulfides were derived from in situ melting of pre-existing sulfides, potentially associated with mafic intrusions in the target area. The ore-forming processes at Sudbury thus would seem to be unique and are not expected to apply to other layered intrusions formed by continental magmatism.

\section{Uitkomst and Voisey's Bay: Two Mineralized Conduit Systems}

The Uitkomst intrusion of South Africa and its associated sulfide ores were first described by Wagner in 1929. However, the full extent of the mineralization long remained unknown, despite the prospecting efforts of several mining companies, and it was only in the early 1990s that diamond drilling proved the existence of economically exploitable ore reserves. The intrusion is a plunging tubular body measuring approximately $0.8 \mathrm{~km}$ in diameter and at least $8 \mathrm{~km}$ in length (Figs. 1B, C), but geophysical data suggest considerable extension at depth. The body consists of a thin basal gabbro, overlain by some $450 \mathrm{~m}$ of peridotite (harzburgite and pyroxenite), and some 250 to $300 \mathrm{~m}$ of gabbronorite and diorite. The magma concordantly intruded gently dipping dolomites and shales of the late Archean Transvaal Supergroup, apparently exploiting bedding planes (Gauert et al. 1995). The lower $100 \mathrm{~m}$ of the intrusion contain disseminated sulfide ores $(97 \mathrm{Mt}$ at $0.55 \% \mathrm{Ni}$ and $0.21 \% \mathrm{Cu}$ ). There are three pods of massive sulfide $(2.9 \mathrm{Mt}$ at $2.04 \% \mathrm{Ni}$ and $1.13 \% \mathrm{Cu}$ ) intruding the immediate floor of Archean basement gneiss. The Uitkomst body has been interpreted as a magma conduit by Gauert et al. (1995), on the basis of its tubular shape, the large proportion of sulfide and chromite to silicate, and the lack of differentiation in the ultramafic units. This interpretation was supported by Maier $e t a l$. (1998), who showed that successive units of the body all crystallized from magma that was fertile in terms of its chalcophile metal content. Most recently, De Waal et al. (2001) demonstrated that the bulk of the intrusion crystallized from magma similar in composition and age to the high-magnesium basaltic parental magmas of the $2.06 \mathrm{Ga}$ Bushveld Complex.

The Voisey's Bay Ni-Cu-Co sulfide deposit is associated with a troctolitic to gabbroic intrusion, one of the smallest members of the $1.3 \mathrm{Ga}$ Nain Plutonic Suite, which consists of a group of troctolitic, gabbroic, anorthositic, dioritic and granitic intrusions covering an area of approximately $15000 \mathrm{~km}^{2}$ in northern Labrador (Fig. 2A). It is the only known major Ni-Cu sulfide deposit associated with an anorthosite suite. The Voisey's Bay intrusion comprises a lower chamber connected by a $1 \mathrm{~km}$ sheet or dyke conduit to an upper chamber (Figs. 2B, C; Ryan et al. 1995, Li \& Naldrett 1999, Li et al. 2000). The upper chamber and much of the conduit are hosted by orthogneiss, whereas the lower chamber is hosted by sulfide-bearing paragneiss. Important sulfide mineralization occurs within widened sections of the conduit and at its entry into the upper chamber, where it is closely related to inclusions of paragneiss that were entrained from the lower chamber. Reaction with the gneiss resulted in $\mathrm{K}, \mathrm{Na}, \mathrm{SiO}_{2}, \mathrm{H}_{2} \mathrm{O}$, and sulfur entering the magma, leaving behind an $\mathrm{Al}-$ rich residuum composed of hercynite and labradorite $(\mathrm{Li}$ et al. 2000, Lambert et al. 1999, Ripley et al. 1999). The multiple-element contamination, in particular the addition of crustal sulfur from the paragneiss, brought the magma to a state of S-oversaturation, with the resultant segregation of an immiscible sulfide liquid. The sulfides and the country-rock inclusions became lodged in and near the conduit as the magmas ascended from 

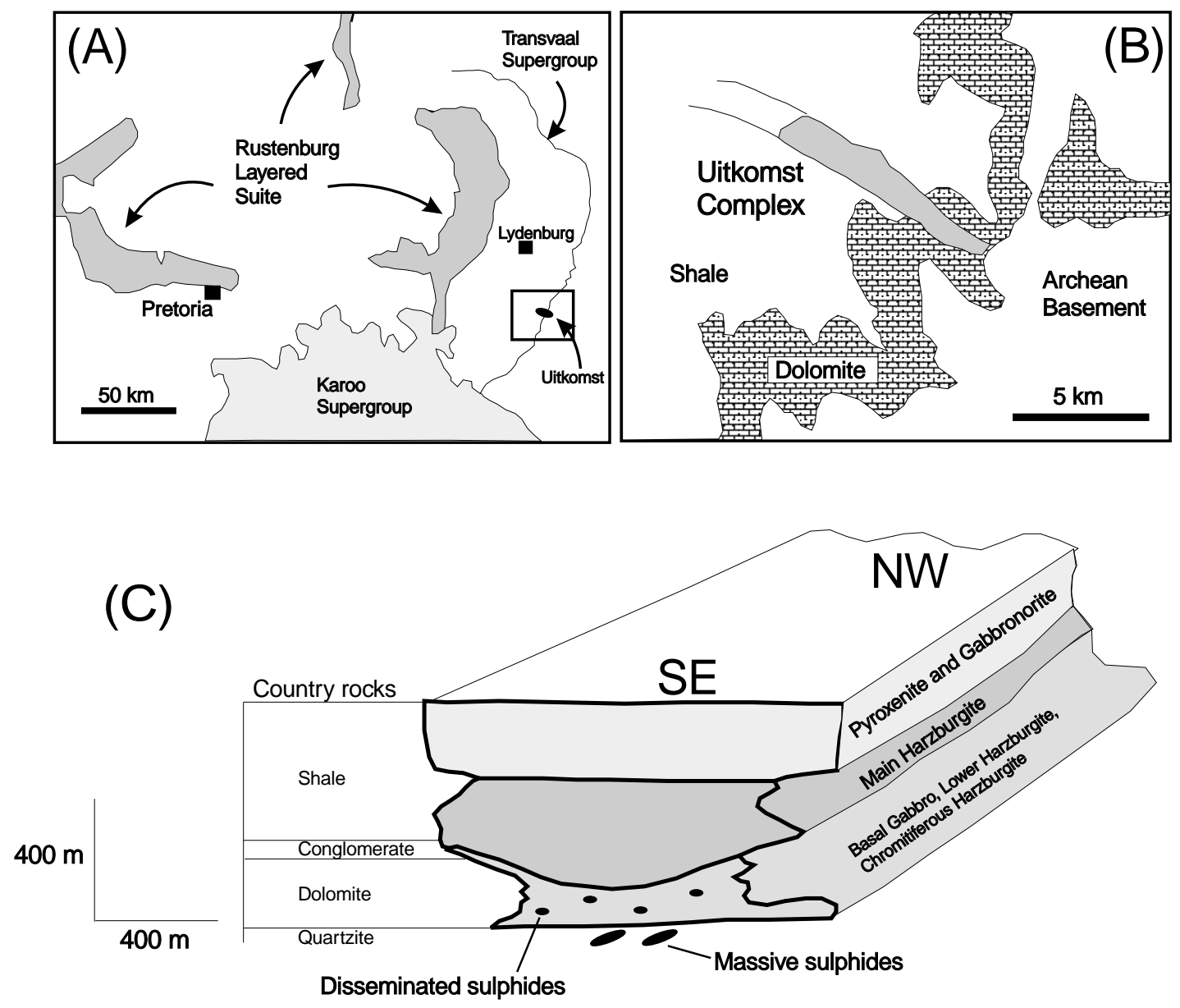

FIG. 1. A. Locality map of the Uitkomst Complex. B. Simplified geological map of the area hosting the Uitkomst Complex. C. Schematic section through the Uitkomst Complex.

the lower chamber to the upper chamber and were upgraded in metal content by continued surges of fresh magma exploiting the conduit.

\section{Bushveld and Kiglapait: Two Large Sulfide-Poor LAYERED INTRUSIONS}

The Bushveld Complex is a composite intrusion consisting of a granitic, granophyric, and layered maficultramafic phase. It constitutes the world's largest layered intrusion, extending over $65000 \mathrm{~km}^{2}$ and measuring some 7-9 km in thickness (Fig. 1A). An overview of the Complex is provided in Eales \& Cawthorn (1996, and references therein). The floor rocks of the Complex are mostly quartzites and volcanic rocks of the Transvaal Supergroup, as well as Archean granitegneiss. The roof comprises rhyolites and granophyre, the latter considered to be metamorphosed and partially molten rhyolite or quartzofeldspathic sediments. The layered sequence contains several stratiform horizons 0.05 to $1.5 \mathrm{~m}$ thick, which host the bulk of the world's reserves in platinum-group elements. In most cases, the $\mathrm{S}$ content of these layers is less than $500 \mathrm{ppm}$, with the exception of the Merensky Reef, which may contain up to $3 \%$ sulfides (Naldrett 1989). In the northern parts of the Complex, somewhat higher sulfide contents (but mostly <5\%: Gain \& Mostert 1982) are found near its basal contact, forming the Platreef. Notably, the floor rocks to the Platreef differ somewhat from those in the remainder of the Complex, consisting of iron formation and dolomite of the Transvaal Supergroup and Archean basement granite. Elevated concentrations of sulfides are generally associated with xenoliths of dolomite (Gain \& Mostert 1982), suggesting that localized assimi- 


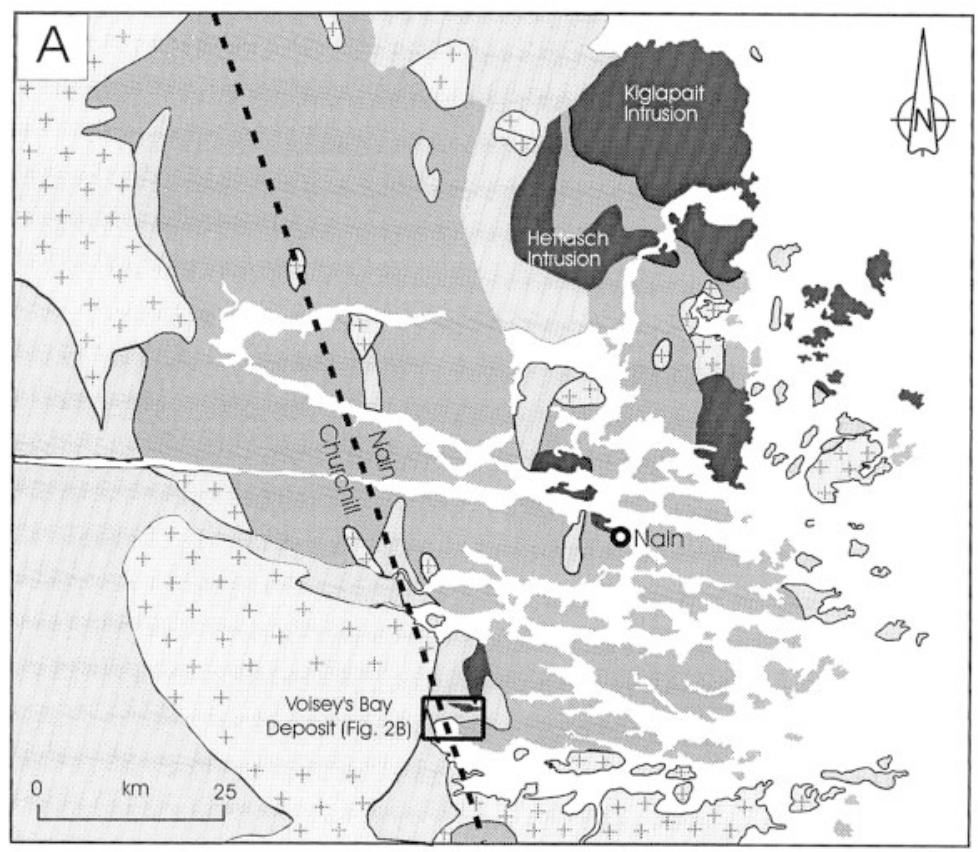

Nain Plutonic Suite ++ Granitoid intrusions $\square$ Anorthositic intrusions $\square$ Troctolite Basement $\square$ Gneiss

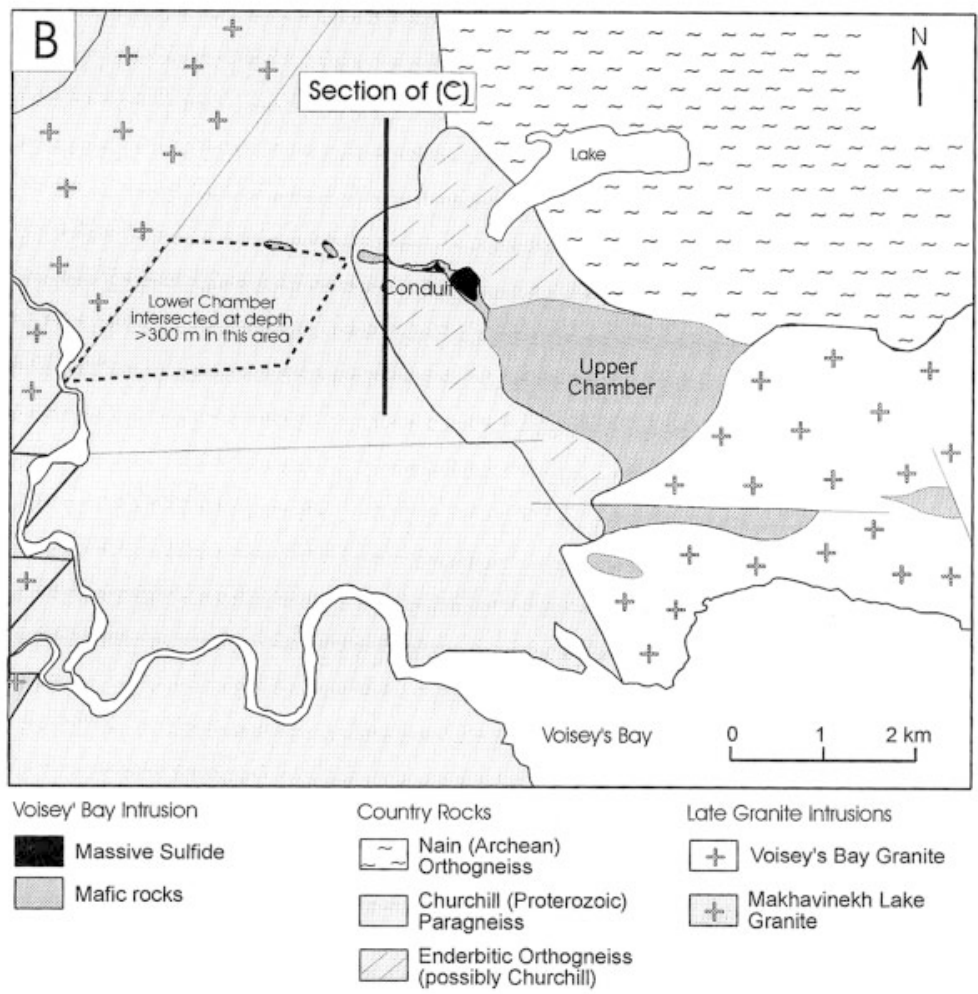




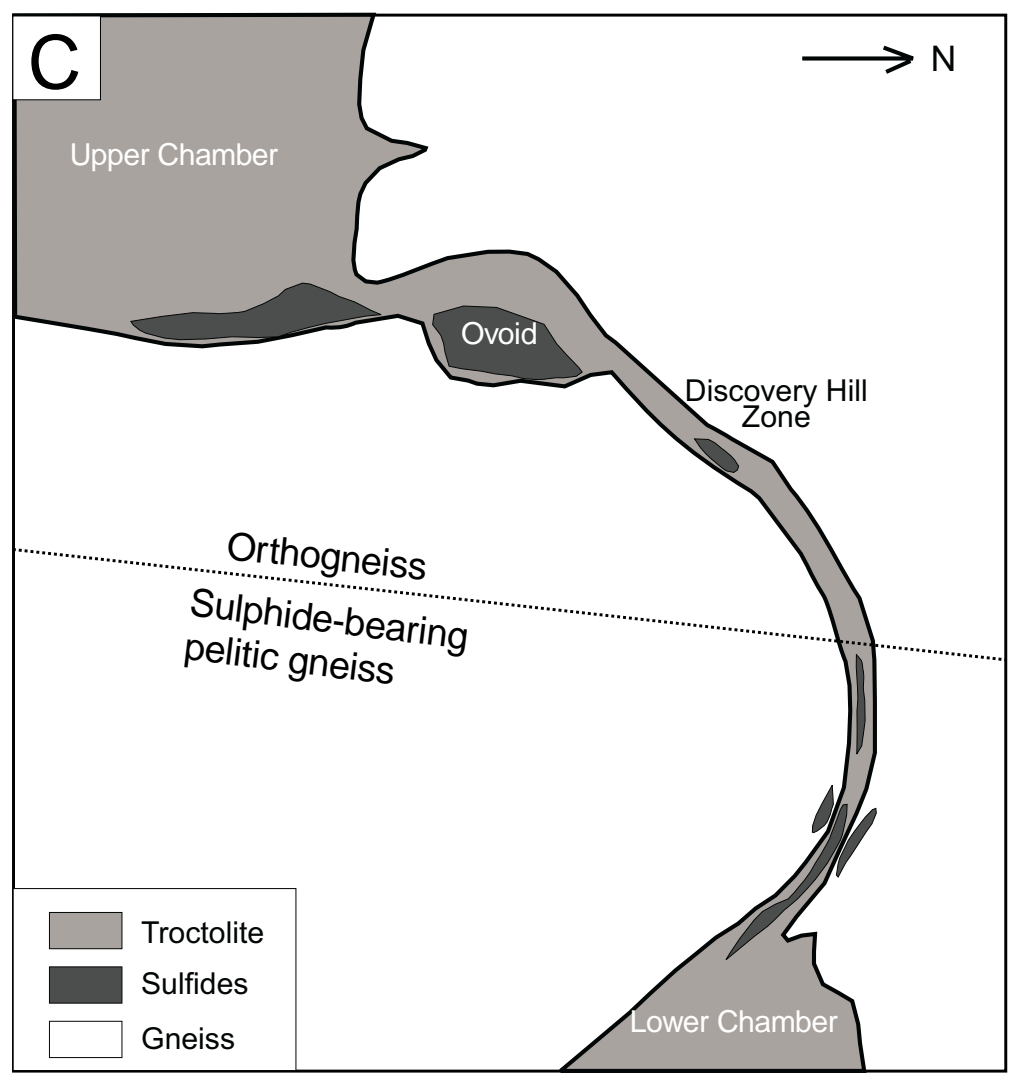

FIG. 2. Geological map of (A) the Nain Plutonic Suite, and (B) the Voisey's Bay area. Solid line represents the conceptual section shown in C. C. West-facing conceptual section of the Voisey's Bay intrusion. The lower and upper chambers as well as the conduit are projected into the section (modified after Ryan 1990, Li \& Naldrett 1999, Lightfoot \& Naldrett 1999).

lation of the floor rocks may have triggered sulfide segregation. The Bushveld Complex hosts a few minor showings of massive sulfide, most notably the Vlakfontein Ni pipes (Vermaak 1976). Several of the larger bodies, measuring, on average, $5 \mathrm{~m}$ in diameter and $110 \mathrm{~m}$ in depth, were mined in the past. The ores were long ago interpreted to have been injected from a pool of sulfide at the base of the Bushveld Complex (Schwellnus 1935), i.e., a model that was possibly influenced by what has been observed at Sudbury. In the 1960s, this led to the unsuccessful drilling of more than $5000 \mathrm{~m}$ of borehole core focussing on the basal contact of the intrusion.

The Kiglapait intrusion is the largest mafic layered intrusion of the Nain Plutonic Suite (Fig. 2A). The body is some $500 \mathrm{~km}^{2}$ in size and up to $9 \mathrm{~km}$ thick. It consists of troctolite and lesser gabbroic rocks, and appears to have crystallized as a largely closed system, i.e., without experiencing major replenishments of magma
(Morse 1969). As in the case of many other large layered intrusions in the world, it was thoroughly explored for both basal $\mathrm{Ni}-\mathrm{Cu}$ sulfide ores and reef-type PGE deposits by various mining companies, particularly after the discovery of the Voisey's Bay deposit, which is associated with another mafic intrusion of the Nain Plutonic Suite. Disseminated sulfide mineralization was found in two environments (Morse 1969, Kerr \& Ryan 2000). One of these consists of the uppermost portions of the layered sequence ( $98 \%$ crystallized), after S saturation was reached. Because of the preceding fractionation of olivine, these sulfides are Ni-poor. The second environment is associated with dyke-like bodies of pyroxenite intruding the lower layered sequence of the intrusion. The pyroxenites are considered to have developed through contamination of mafic magma by sulfide-bearing footwall gneisses. The sulfides are poor in both $\mathrm{Ni}$ and $\mathrm{Cu}$, usually at less than $1 \%$, and are currently subeconomic. 


\section{OTHER LARGE LAYERED INTRUSIONS}

Many other large layered intrusions, including the Great Dyke of Zimbabwe (Wilson et al. 1989), the Munni Munni (Barnes et al. 1990) and Windimura intrusions (Parks \& Hill 1986) of Western Australia, the Skaergaard intrusion of Greenland (Andersen et al. 1998), and the Penikat intrusion of northern Finland (Alapieti \& Lahtinen 1986) host only minor occurrences of disseminated stratiform sulfide, generally some distance above the base of the intrusions. These are, however, commonly highly enriched in PGE. Elevated contents of disseminated sulfide near the base of intrusions are described from just a few layered intrusions, including the Stillwater and Duluth complexes.

The Basal Series of the 2.7 Ga Stillwater Complex consists of a variety of coarse-grained rocks, including orthopyroxenite, norite, anorthosite, gabbro and peridotite, as well as xenoliths of hornfels. Sulfides are mainly disseminated, reaching $20 \%$ within a $60 \mathrm{~m}$ zone near the basal contact of the Complex (Zientek et al. 1986, McCallum 1996, and references therein). Sills of mafic norite in the floor of the Complex and metasedimentary country-rocks (iron formation, shale and graywacke) contain 2-40\% sulfides in places (Zientek et al. 1986, McCallum 1996). However, all occurrences, at combined $\mathrm{Cu}$ and $\mathrm{Ni}$ of $0.5 \%$, have low tenors.

The Duluth Complex consists of a suite of gabbroic, gabbronoritic, troctolitic, anorthositic and granitic intrusions of Mid-Proterozoic age (1100 Ma) exposed over an area of $5000 \mathrm{~km}^{2}$ in northern Minnesota. It represents a staging chamber to the Keweenawan flood basalts (Miller \& Ripley 1996). Disseminated sulfides (6 Gt at $0.66 \% \mathrm{Cu}$ and $0.2 \% \mathrm{Ni}$, several hundred ppb PGE; Ripley 1990) that locally grade into minor zones of massive ore are concentrated in the basal $250 \mathrm{~m}$ of troctolitic intrusions that invade iron formation, siltstones, graywackes, and sulfide-bearing argillites. As in the case of the Platreef of the Bushveld Complex, elevated sulfide contents are commonly observed adjacent to country-rock xenoliths (Thériault et al. 1997).

We know of just a few additional examples where minor accumulations of massive magmatic ores are found associated with the base of layered intrusions. These include the Suhanko intrusion of northern Finland (Iljina et al. 1992), the Rana intrusion of Norway (Boyd \& Mathiesen 1979), and the Muskox intrusion of northern Canada (Barnes \& Francis 1995), but the sulfide ores in these intrusions are either too low in $\mathrm{Ni}$ and $\mathrm{Cu}$ contents or too small in size to make them economic deposits.

\section{DisCUSSION}

Large layered intrusions worldwide are a prime target for stratiform sulfide-bearing PGE deposits, but there appears to be a distinct tendency for these intrusions to lack economically important $\mathrm{Ni}-\mathrm{Cu}$ sulfide ores. In the case of the Bushveld and Stillwater complexes, this is particularly surprising, since the conditions considered necessary to produce such accumulations of ores are met: (1) The parental magmas to the Complexes were fertile in terms of their chalcophile metal contents and had not experienced significant saturation in sulfide before emplacement (Davies \& Tredoux 1985, Maier et al. 1996). (2) The Bushveld chamber was frequently replenished with magmas of contrasting composition (Eales \& Cawthorn 1996), thereby providing ideal conditions for magma mixing and oversaturation with respect to sulfur. (3) The volume of magma was large enough to provide enough $\mathrm{Ni}$ and $\mathrm{Cu}$ for sizeable sulfide deposits. (4) $\mathrm{Sr}$ and $\mathrm{Nd}$ isotopic data indicate significant amounts (20-40\%) of contamination of the magma with a crust component (Kruger 1994, Maier et al. 2000).

A clue to the scarcity of significant sulfide deposits in the Bushveld and other large layered intrusions was provided by Mavrogenes \& O'Neill (1999). They confirmed the earlier findings of Wendlandt (1982), who suggested that S-solubility in basalt increases with decreasing pressure. The new data indicate an increase in the solubility of approximately $10 \mathrm{ppm}$ per one kbar decreasing pressure. The authors therefore suggested that ascending mantle-derived magmas are generally Sundersaturated upon emplacement and that large-scale assimilation of crustal $\mathrm{S}$ is necessary to cause oversaturation with respect to $\mathrm{S}$ and to form large deposits of magmatic sulfides (Lesher \& Stone 1996).

What then caused the conduit systems at Voisey's Bay, Uitkomst and other localities such as Jinchuan and Noril'sk to be mineralized at economic grades? A key observation is that the total amount of sulfides in the Platreef by far exceeds that in the Uitkomst intrusion, but the sulfides are diluted by silicates and dispersed over a large area. Thus, we contend that the flow dynamics of magmas in conduit systems are critical in the formation of a magmatic sulfide ore deposit. Li et al. (2000) suggested that in the Voisey's Bay intrusion, sulfides segregated in a lower staging chamber owing to contamination with sulfide-bearing country rocks. They were then entrained and transported during continued and rapid ascent of the magma through the conduit system. The sulfide melt preferentially precipitated where the flow velocity of the magma decreases, i.e., in widened parts of the conduit and at the entry of the conduit into an upper chamber (Figs. 2C, 3). Continued surges of undepleted magma flowing through the conduit stirred up earlier, unconsolidated pools of sulfide (the "proto-ores"), remobilized the sulfides, and upgraded them in metal content (Fig. 3). Proto-sulfides that injected into the floor, or were shielded from further reaction by solidified magma, were not upgraded and may have remained uneconomic (Fig. 3). Notably, clear intrusive relationships between rocks that contain metalenriched sulfides and those that contain metal-depleted sulfides are not evident at Voisey's Bay, which is con- 


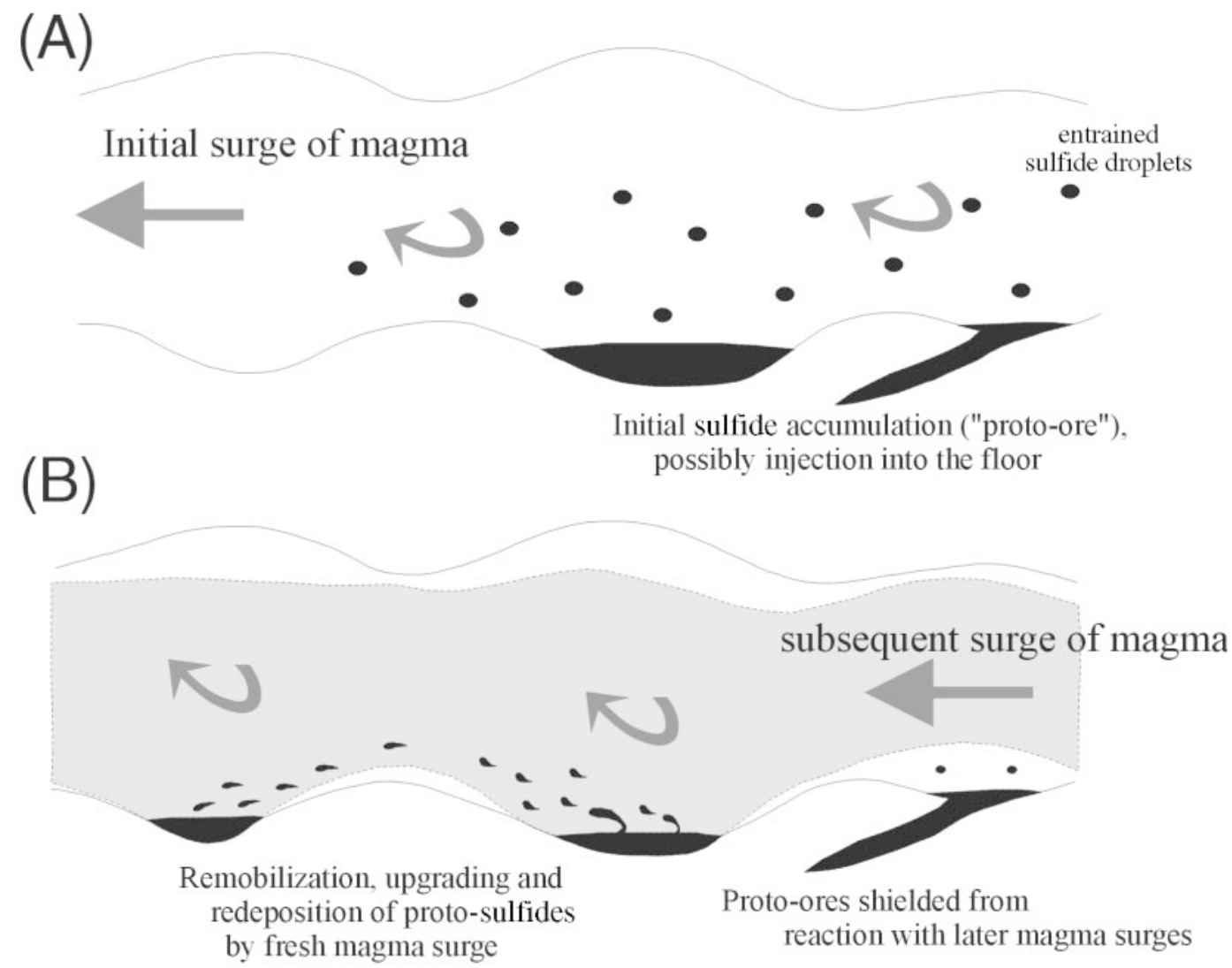

FIG. 3. Schematic diagram illustrating the continued flow of magma through an idealized conduit. A. Initial surge of magma carries entrained sulfide droplets, which may be deposited in widened parts of the conduit to form the "proto-ore". In places, sulfide melt may inject into the floor. B. Continued surges of undepleted magma stir up the previously accumulated sulfide melt, upgrading it in $\mathrm{Cu}, \mathrm{Ni}$ and $\mathrm{PGE}$, and reprecipitating it downstream in the conduit. Proto-ores that injected into the floor may remain shielded from reaction and upgrading in metal content.

sistent with a model of continued surges of magma using the same conduit.

De Bremond d'Ars et al. (1999) attempted to quantify the transport of sulfide melt by silicate magma. They demonstrated that magmas flowing upward through dykes may carry sulfide droplets of around $1 \mathrm{~cm}$ in diameter in suspension, and that it is the size of the droplets and the upward velocity of flow of the magma rather than the density of the sulfide and the viscosity of the magma that exert the main controls on the sulfidecarrying capacity.

Our interpretation is supported by the observation that in many conduit-type environments (Noril'sk, Voisey's Bay, Uitkomst), one finds both units containing Ni-depleted olivine and undepleted units that contain Ni-rich olivine. Notably, it is the metal-depleted units that are sulfide-poor, e.g., the early olivine gabbro at Voisey's Bay and the basal gabbro at Uitkomst. We interpret them to have crystallized from magma that experienced sulfide segregation in a lower staging chamber or upstream in the conduit. In contrast, the units containing Ni-enriched olivine commonly contain sulfides. We contend that these rocks crystallized from later surges of magma that entrained early sulfides (the "proto-ore") and upgraded them in metal content.

An alternative or additional mechanism of ore formation may involve localized oversaturation in sulfur due to enhanced rates of assimilation of appropriate country-rocks in magma conduits. Once the magma entered a larger chamber, it would hybridize with larger volumes of S-undersaturated magma, and any suspended droplets of sulfide could be expected to dissolve. However, at Voisey's Bay, much of the mineralized upper portion of the conduit is hosted by S-poor orthogneiss (Fig. 2C), and it therefore appears that the sulfides did not form in situ. At Uitkomst, the situation is less clear, with both S-poor and S-rich sediments hosting the intrusion. 
It remains uncertain whether metal upgrading of sulfides within magma conduits also has implications for the formation of reef-type PGE deposits in large layered intrusions. If sulfides that are lodged in magma conduits are progressively dissolved by successive pulses of ascending S-undersaturated magma, the residual sulfides may become progressively PGE-enriched. That pulse of ascending magma dissolving the last fraction of sulfides would be highly metal-enriched and could segregate relatively PGE-rich sulfides upon emplacement. In the case of the Bushveld Complex, this model appears inappropriate. The entire Lower and Critical zones have been shown to be PGE-enriched (Maier \& Barnes 1999), and thus the magmas from which these cumulates crystallized could not have equilibrated with sulfides during ascent.

\section{Conclusions}

Examination of the nature of the sulfide mineralization in the world's layered intrusions and associated conduit-systems suggests that large layered intrusions are poor targets for economically important magmatic deposits of $\mathrm{Ni}-\mathrm{Cu}$ sulfide ore. Magma-conduit systems are more promising for such ores, because the conduits provide ideal environments of deposition for any sulfides entrained in ascending silicate magmas. Deposition could occur over limited areas, to form massive or highly concentrated bodies of sulfide ore. Further, the sulfides can be upgraded in $\mathrm{Ni}, \mathrm{Cu}$ and PGE by new surges of magma using the same conduit. In contrast, sulfur saturation in large layered intrusions may occur as a result of differentiation, and in such a case small amounts of precipitating sulfides would be diluted by accumulating silicates. Also, the sulfides are commonly dispersed over a large area owing to the absence of a mechanism of concentration. And finally, segregated sulfides commonly have low $\mathrm{Cu}$ and $\mathrm{Ni}$ tenors owing to the lack of an efficient metal-upgrading process.

\section{ACKNOWLEDGEMENTS}

Funding for this project was provided by Research Development Grants of the University of Pretoria to WDM and CL. The authors thank S.-J. Barnes, N.T. Arndt, R.F. Martin, A.R. McBirney and an anonymous reviewer for their critical reviews, which significantly improved the manuscript.

\section{REFERENCES}

AlAPIETI, T.T. \& LAhTinEN, J.J. (1986): Stratigraphy, petrology, and platinum-group element mineralization of the early Proterozoic Penikat layered intrusion, northern Finland. Econ. Geol. 81, 1126-1136.

Andersen, J.C.Ø., Rasmussen, H., Nielsen, T.F.D. \& Rønsbo, J.G. (1998): The Triple Group and the Platinova gold and palladium reefs in the Skaergaard Intrusion: stratigraphic and petrographic relations. Econ. Geol. 93, 488-509.

BARNES, S.-J. \& FRANCIS, D. (1995): The distribution of platinum-group elements, nickel, copper, and gold in the Muskox layered intrusion, Northwest Territories, Canada. Econ. Geol. 90, 135-154.

Barnes, S.J., McIntyre, J.R., Nisbet, B.W. \& Williams, C.R. (1990): Platinum group element mineralization in the Munni Munni Complex, Western Australia. Mineral. Petrol. 42, 141-164.

Boyd, R \& MATHIESEN, C.O. (1979): The nickel mineralization of the Rana mafic intrusion, Nordland, Norway. Can. Mineral. 17, 287-298.

Davies, G. \& Tredoux, M. (1985): The platinum-group element and gold contents of the marginal rocks and sills of the Bushveld Complex. Econ. Geol. 80, 838-848.

De Bremond D'Ars, J., Arndt, N.T. \& Hallot, E. (1999): Analog experimental investigation of the formation of magmatic sulphide deposits. In Mineral Deposits: Processes to Processing (C.J. Stanley, et al., eds.). Proc. 5th SGA Meeting, 705-708.

De WaAl, S.A., Maier, W.D., Gauert, C.D.K. \& Armstrong, R.A. (2001): Parental magma and emplacement of the stratiform Uitkomst Complex, South Africa. Can. Mineral. 39, 557-571.

EAles, H.V. \& CAwthorn, R.G. (1996): The Bushveld Complex. In Layered Intrusions (R.G. Cawthorn, ed.). Elsevier, Amsterdam, The Netherlands (181-229).

Gain, S.B. \& Mostert, A.B. (1982): The geological setting of the platinoid and base metal sulfide mineralization in the Platreef of the Bushveld Complex in Drenthe, north of Potgietersrus. Econ. Geol. 77, 1395-1404.

Gauert, C.D.K., De WaAl, S.A. \& Wallmach, T. (1995): Geology of the ultrabasic to basic Uitkomst Complex, eastern Transvaal, South Africa: an overview. J. Afr. Earth Sci. 21, 553-570.

Grieve, R.A.F. (1994): An impact model of the Sudbury structure. In Proceedings of the Sudbury-Noril'sk Symposium (P.C. Lightfoot \& A.J. Naldrett, eds.). Ontario Geol. Surv., Spec. Vol. 5, 119- 132.

ILJinA, M.J., AlaPIETI, T.T. \& McEldRUfF, B.M. (1992): Platinum-group element mineralization in the Suhanko-Konttijärvi intrusion, Finland. Aust. J. Earth Sci. 39, 303-313.

KerR, A. \& Ryan, B. (2000): Threading the eye of the needle: lessons from the search for another Voisey's Bay in Labrador, Canada. Econ. Geol. 95, 725-748.

KRUGER, F.J. (1994): The Sr isotopic stratigraphy of the western Bushveld Complex. S. Afr. J. Geol. 97, 393-398. 
Lambert, D.D., Foster, J.G., Frick, L.R., Li, Chusi \& NALDRETT, A.J. (1999): Re-Os isotopic systematics of the Voisey's Bay Ni-Cu-Co magmatic ore system, Labrador, Canada. Lithos 47, 69-88.

LESHER, C.M. \& STONE, W.E. (1996): Exploration geochemistry of komatiites. In Trace Element Geochemistry of Volcanic Rocks: Applications for Massive Sulphide Exploration (D.A. Wyman, ed.). Geol. Assoc. Can., Short Course Notes 12, 153-204.

Li, Chusi, Lightfoot, P.C., Amelin, Y. \& Naldrett, A.J. (2000): Contrasting petrological and geochemical relationships in the Voisey's Bay and Mushuau intrusions, Labrador, Canada: implications for ore genesis. Econ. Geol. 95, 771-799.

\& NALDRETT, A.J. (1993): Sulfide capacity of magma: a quantitative model and its application to the formation of the sulphide ores at Sudbury. Econ. Geol. 88, 1253-1260.

\& (1999): Geology and petrology of the Voisey's Bay intrusion: reaction of olivine with sulphide and silicate liquids. Lithos 47, 1-31.

Lightfoot, P.C. \& NALdRetT, A.J. (1999): Geological and geochemical relationships in the Voisey's Bay Intrusion, Nain Plutonic Suite, Labrador, Canada. In Dynamic Processes in Magmatic Ore Deposits and their Application to Mineral Exploration (R.R. Keays, C.M. Lesher, P.C. Lightfoot \& C.F.G. Farrow, eds.). Geol. Assoc. Can., Short Course Notes 13, 1-30.

Maier, W.D., Arndt, N.T. \& Curl, E. (2000): Progressive crustal contamination of the Bushveld Complex: evidence from Nd isotopic analyses of the cumulate rocks. Contrib. Mineral. Petrol., in press.

\& BARNES, S.-J. (1999): Platinum-group elements in silicate rocks of the Lower, Critical and Main zones at Union Section, western Bushveld Complex. J. Petrol. 40, 1647-1671.

\& DE WAAL, S.A. (1998): Exploration for magmatic Ni-Cu-PGE sulphide deposits: a review of recent advances in the use of geochemical tools, and their application to some South African ores. S. Afr. J. Geol. 101, 237-253.

Teigler, B., De Klerk, W.J. \& Mitchell, A.A. (1996): Cu/Pd and Cu/Pt of silicate rocks in the Bushveld Complex: implications for platinum-group element exploration. Econ. Geol. 91, 1151-1158.

Mavrogenes, J.A. \& O'Neil, H.St.C. (1999): The relative effects of pressure, temperature and oxygen fugacity on the solubility of sulphide in mafic magmas. Geochim. Cosmochim. Acta 63, 1173-1180.

McCallum, I.S. (1996): The Stillwater Complex. In Layered Intrusions (R.G. Cawthorn, ed.). Elsevier, Amsterdam, The Netherlands (441-483)
MilleR, J.D., JR. \& RIPLEY, E.M. (1996): Layered intrusions of the Duluth Complex, Minnesota, USA. In Layered Intrusions (R.G. Cawthorn, ed.). Elsevier, Amsterdam, The Netherlands (257-301).

Morse, S.A. (1969): The Kiglapait layered intrusion, Labrador. Geol. Soc. Am., Mem. 112.

NALDRETt, A.J. (1989): Magmatic Sulphide Deposits. Oxford University Press, Oxford, U.K.

PARKs, J. \& HiLl, R.E.T. (1986): Phase compositions and cryptic variation in a $2.2-\mathrm{km}$ section of the Windimurra layered gabbroic intrusion, Yilgarn Block, Western Australia - a comparison with the Stillwater Complex. Econ. Geol. 81, 1196-1202.

RIPLEY, E.M. (1990): Platinum-group element geochemistry of $\mathrm{Cu}-\mathrm{Ni}$ mineralization in the basal zone of the Babbitt deposit, Duluth Complex, Minnesota. Econ. Geol. 85, 830841.

NALDRETt, A.J., PARK, Y.-R. \& Li, Chusi (1999): Sulfur and oxygen isotopic evidence of country rock contamination in the Voisey's Bay Ni-Cu-Co deposit, Labrador, Canada. Lithos 47, 53-68.

RYAN, B. (1990): Geological map of the Nain Plutonic Suite and surrounding rocks (Nain-Nutak, NTS 14SW). Geol. Surv. Newfoundland, Map 90-44.

Wardle, R.J., Gower, C.F. \& NunN, G.A.G. (1995): Nickel-copper sulphide mineralization in Labrador: the Voisey's Bay discovery and its exploration implications. Geol. Surv. Newfoundland, Current Res. Rep. 951, 177-204.

Schwellnus, C.M. (1935): The nickel-copper occurrences in the Bushveld Igneous Complex, west of the Pilanesberg. Geol. Surv. S. Afr., Bull. 5.

Thériault, R.D., Barnes, S.-J. \& Severson, M.J. (1997): The influence of country-rock assimilation and silicate to sulfide ratios ( $\mathrm{R}$ factor) on the genesis of the Dunka Road $\mathrm{Cu}-\mathrm{Ni}$ - platinum group element deposit, Duluth Complex, Minnesota. Can. J. Earth Sci. 34, 375-389.

VermaAK, C.F. (1976): The nickel pipes of Vlakfontein and vicinity, western Transvaal. Econ. Geol. 71, 261-286.

Wagner, P.A. (1929): The Platinum Deposits and Mines of South Africa. Oliver and Boyd, Edinburgh, U.K.

Walker, R. J., Morgan, J.W., Naldrett, A.J., Li, Chusi \& FASSETT, J. (1991): Re-Os isotopic systematics of $\mathrm{Ni}-\mathrm{Cu}$ sulphide ores, Sudbury igneous Complex, Ontario: evidence for a major crustal component. Earth Planet. Sci. Lett. 105, 416-429.

WENDLANDT, R.F. (1982): Sulphide saturation of basalt and andesite melts at high pressures and temperatures. Am. Mineral. 67, 877-885. 
Wilson, A.H., NaldretT, A.J. \& TredouX, M. (1989): Distribution and controls of platinum group element and base metal mineralization in the Darwendale subchamber of the Great Dyke, Zimbabwe. Geology 17, 649-652.
Zientek, M.L., Foose, M.P. \& MeI, Leung (1986): Palladium, platinum, and rhodium contents of rocks near the lower margin of the Stillwater Complex, Montana. Econ. Geol. 81, 1169-1178.

Received March 17, 2000, revised manuscript accepted July 18,2000 